\title{
SOME REMARKS ABOUT GONZALO RODRIGUEZ-PEREYRA'S ADVICE ON THE LANGUAGE OF PHILOSOPHY
}

\author{
MARCO RUFFINO \\ Universidade Federal do Rio de Janeiro/CNPq - Brazil \\ ruffinomarco@gmail.com
}

SUMMARY: In this paper I discuss Gonzalo Rodriguez-Pereyra's notes on the proper language for publishing texts in analytic philosophy. I am basically in agreement with him on the practical side, i.e., publishing in English increases the chances of philosophical exchange with other communities. I disagree, however, if one wants to read a stronger "should" in his advice, for there is nothing in the essence of analytic philosophy that ties it to the English language. Finally, I end with a caveat that his advice should not be misunderstood and degenerate into an exhortation of what I call "linguistic laziness".

KEY WORDS: analytic philosophy, dialog, criticism, linguistic laziness, history of analytic philosophy

RESUMEN: En este artículo discuto la nota de Gonzalo Rodriguez-Pereyra sobre la lengua apropiada para publicar textos en filosofía analítica. Básicamente coincido con él en el aspecto práctico, es decir, que publicar en inglés aumenta la posibilidad de interacción con otras comunidades. Sin embargo, discrepo si acaso el "debería" cobra más fuerza en sus consideraciones, ya que no hay nada en la esencia de la filosofía analítica que la ate a la lengua inglesa. Concluyo con la advertencia de que su consejo no debe ser mal interpretado y degenerar en un exhorto a lo que yo denomino "flojera lingüística".

PALABRAS CLAVE: filosofía analítica, diálogo, crítica, flojera lingüística, historia de la filosofía analítica

Although Gonzalo Rodriguez-Pereyra is a very fine philosopher, his note "The Language of 'Analytic' Philosophy" is not a piece of philosophical work properly speaking. It is not even a work on metaphilosophy, i.e. it is not about the nature of philosophical problems or the proper methodology for solving them. His note is concerned with a strictly practical question, namely, the language in which one should write and publish original philosophical work. Hence, my comments on Gonzalo's note are not meant to be philosophical either, but only as remarks about the practicality of doing philosophy in English. Gonzalo restricts his discussion to contemporary analytic philosophy; I will follow him and simply write 'philosophy' meaning by it only contemporary analytic philosophy. (Like Gonzalo, I will not try to explain what I understand by analytic philosophy, but will rely on a common understanding of it. He is silent about formal logic, but 
since I think that some substantial contributions to contemporary analytic philosophy come from the technical and semi-technical works of prominent logicians, I will use 'philosophy' as covering formal logic as well.) His text does not intend to bring to light any essential aspect of philosophy in connection with the language in which it was produced. This is so because he does not give any decisive weight to the fact that a great number of the classics that are relevant to large parts of philosophy were written in languages other than English (such as Greek, Latin, German, etc.) and that a smaller but no less important part in the language of symbolic (first and higher-order, modal, etc.) logic.

Gonzalo's thesis is simply that analytic philosophy should be written and published only in English. Since it is not concerned with the essence or point of doing philosophy nor with philosophical methodology, the 'should' present in its formulation must be understood as highly hypothetical and relative. On the one hand, it is relative to several contingent facts about the philosophical profession nowadays (like the current state of communication technology, the nationality and linguistic skills of most workers in the field, etc.). On the other hand, it is relative to particular interests that professional philosophers might have (e.g., getting papers published in important journals, being read by a larger group of specialists around the world, or reaching a wider public, etc.). In this aspect, the question proposed is as important as it is for any other area of research: in which language should one write and publish texts in biology, computer science, mathematics, history, etc., nowadays? I mean that answering Gonzalo's question reveals nothing specific about philosophy. So, instead of saying, as I said above, that Gonzalo advances a thesis, I should rather say that he proposes a practical (in the most basic sense) advice.

In this highly qualified and hypothetical sense of 'should', Gonzalo's proposal seems trivially correct to me: one should write in English if one wants to improve his chances of being read by (and getting critical background from) a larger group of people. It is simply a fact that, in this particular period of history, English is the most widely understood and spoken language (at least among scholars and people doing research), and that most of the serious and original work in philosophy is produced in English. But this is, again, highly hypothetical and relative to some particular or specific goals. If, for instance, the goal is not simply to reach a larger group of people, but also to be understood with absolute clarity and precision, then probably English is not the best language; maybe one should write in 
the set theoretic notation or in the language of first order logic. (That was in part what motivated Leibniz' ideal of a lingua characterica and Frege's conception of a Begriffsschrift.)

Gonzalo reviews a number of arguments that are frequently advanced against writing and publishing in English, all of them very weak and misguided by a confused conception of the purpose of doing (or teaching) philosophy. I will not go over his counter-arguments here; they all seem obviously correct to me. He is right, I think, that in many non-English speaking countries (and perhaps most notably in Latin America) there is still an unjustified prejudice against English as a philosophical (and, broadly speaking, scientific) language, caused mainly by a chronic and pathological confusion among intellectuals between serious theoretical work and political ideology. Because English speaking countries were politically dominant for a long time, and supported many dictatorial regimes and wrongdoings in order to keep and enforce their power, doing philosophy in English is frequently seen as "speaking the language of the empire". (Interestingly enough, there is no such strong reaction against doing philosophy in French, despite French colonial violence in Africa and Asia, or in Spanish, despite the horrors of Spanish colonization in Latin America.) One of the regrettable effects of this ideological prejudice was the multiplication of isolated philosophical groups and local traditions, with their own local standards of relevance and competence, which are, as a rule, poorly informed about recent advances worldwide and, hence, condemned to repetition and irrelevance. Some decades ago, having access to new bibliographical material (and thus being able to keep up with the advances in the field) was much harder and more expensive; hence there was a convenient excuse for becoming isolated from the rest of the world in philosophical research. But nowadays much of the relevant production is on line and available to everyone, and hence there is no longer any such excuse. Another regrettable effect of isolationism and linguistic prejudice was that a strictly historical study of philosophers became the raison d'être for many such isolated groups, for whom trying to solve or even to think by oneself about some fundamental philosophical questions is seen as a ridiculous deviation from the classics.

Gonzalo is right that many (and perhaps most) students and professional philosophers already know English well enough to be able to read or attempt to write philosophy in this language; those who don't know enough can benefit when faced with the real need to learn it in order to get the required reading done for a seminar, or to produce a paper that is publishable or presentable at an international meeting. 
I know from my teaching experience in some non-English speaking countries that, whenever the reading material for a seminar can only be obtained in English (i.e. no translations are available), students with minimal linguistic skills usually take no longer than a couple of weeks to be able to read quite satisfactorily. So, the "language barrier" is not much of a barrier after all, not in the case of English at any rate. English is nowhere a barrier when it comes to dealing with internet, entertainment (e.g., music) or new technology, especially for young people: they normally learn it very easily. Why should it be a barrier when it comes to reading and writing philosophy?

Gonzalo is also right, in my view, in saying that there is a difference between publishing original work in philosophy, and publishing popular versions of it (which might perhaps reach a broader local public if written in a local language). Hardly any serious work was written in philosophy in the form of texts whose primary concern was to popularize philosophical theses and arguments. Serious and original philosophical work is generally highly specialized and hard to digest for those not initiated in the subject. This is so, by the way, in any area of research. It is part of the maturation process of any scientific field that the texts produced by professional researchers are usually understandable at first only to a relatively small circle of specialists, and only later are made available to a broader group of people.

However, despite my overall agreement with him, I must express two misgivings about Gonzalo's advice. First, if he wants to derive from his considerations a stronger 'should' than the strictly practical (in the sense indicated above), then his position is trivially false. If considerations regarding the language of most scholars should constrain the language in which philosophy is produced and published, then I suspect that either we should all still be writing and publishing in Latin, or else be preparing to read and write in Chinese. Second, I understand Gonzalo's text as an exhortation for professionals in Latin America and elsewhere to try to reach a broader group of specialists and, hence, to become exposed to more criticism that will lead, ultimately, to improvement in terms of rigor, originality and relevance. This is highly desirable not only in philosophy, but in any area of research, and in this sense, Gonzalo's advice is welcome. However, as I see it, his advice is incomplete and might easily be misunderstood as an excuse for linguistic laziness. If writing and publishing in English is desirable in order to communicate with a larger group of philosophers, knowing other languages and being able to read and understand authors from other linguistic cultures 
and historical contexts is also an extremely valuable instrument for professional philosophers. What I mean is that not simply writing and publishing in English will lead to better research in philosophy, but also making an effort to read (and perhaps write) philosophy in languages other than English is also desirable.

As the Greeks used to say, if we want to learn what virtue is, we should pay attention to virtuous people. Let us look at some examples in which being able to read and work in languages other than English resulted in notoriously rich and original work in contemporary philosophy. It is undisputable that ancient Greek philosophy has been the source of inspiration for many contemporary leading philosophers such as Davidson, Anscombe, McDowell, Hintikka, to mention only a few. The same is true for medieval philosophy, which deeply influenced people like Geach, Plantinga, etc. Knowledge of Greek and Latin is certainly not a sine qua non condition for reading ancient Greek or medieval philosophy, since there are usually good translations available. But it is highly desirable since it permits a much deeper contact and, hence, a more intimate dialogue with the classics. Another paradigmatic example in which linguistic skills prompted the quality of philosophical work is the trajectory of Quine, who famously knew (and worked in) several languages other than English. He mentions in his autobiography for the Schilpp volume that his "linguistic drive" led him to take classes in several languages (including Greek, German and French) in college. He describes his trip to middle Europe in the 1930s, and says "I gained a firm command of German, and that was a boon. It prepared me for what proved to be the intellectually most rewarding months I have known, namely, my six weeks in Prague and six in Warsaw" (Hahn and Schilpp 1986, p. 12). He also knew fluently Spanish and Portuguese, and even published a seminal work on logic in Portuguese (Quine 1944). No doubt Quine benefited from his contact with many philosophical and logical schools other than those in which English was the official language. Another interesting case of linguistic effort resulting in philosophical insight is that of the late George Boolos, a leading philosopher of logic and mathematics. He comments in the preface of his The Logic of Provability (1993) that the crucial formal result that motivated his entire book was contained in an article published in Russian that was sent to him, and which he spent a week deciphering with a dictionary. (We might wonder what a loss it would have been for analytic philosophy if he had taken too strictly advice like Gonzalo's and ignored a paper in Russian.) Finally, in a somewhat different spirit, 
Frege calls attention to the benefits of knowing several languages for doing philosophical logic:

From this we can see the value of learning foreign languages for one's logical education: when we see that the same thought can be worded in different ways, our minds separate off the husk from the kernel, though, in any given language, it appears as a natural and integral part of it. This is how the differences between languages can facilitate our grasp of what is logical. (Frege 1979, p. 6)

After all, if it is true that a large part of what is done in philosophy (e.g., Strawson, Quine, Dummett, etc.) is essentially guided by language, it is also true that most philosophers understand their results to be independent of the particular language used to formulate and answer the philosophical question. ${ }^{1}$

Everything I am saying here is, of course, compatible with Gonzalo's advice. But what I mean is that his advice might lead to philosophical impoverishment if taken too strictly and as an excuse for linguistic laziness. I remember that, during my years as a Ph.D. student in the U.S., some of my native English speaker colleagues had a great resistance to reading classic material in any language other than English. Some of them even resisted reading material produced in any other philosophical tradition besides Anglo-American analytic philosophy. I remember one of them saying once: "I hate non-analytic literature... because first you have to make an effort to understand it..." This always seemed to me a regrettable attitude. The effort in understanding other (i.e., non-English written and non-strictly-contemporary) philosophy (which might require mastery of other languages besides English and an effort of comparative understanding) has proved extremely fruitful for the analytic tradition itself. I should even say that an essential aspect of the analytic tradition, perhaps more than any other tradition, is its capacity to establish a critical dialogue with (and incorporate insights from) the classics from other periods and linguistic environments. It would be a loss if a monolingual philosophical practice were to replace and destroy this spirit.

\footnotetext{
${ }^{1}$ I have listed only few cases of influential philosophers who cultivate linguistic skills as part of their philosophical jobs. The list of prominent examples could also include people like Charles Parsons, Tyler Burge, Robert Adams, Montgomery Furth, Michael Dummett, Bertrand Russell, J.L. Austin, and many, many others.
} 
SOME REMARKS ABOUT GONZALO RODRIGUEZ-PEREYRA'S ADVICE 105

\section{REFERENCES}

Boolos, George, 1993, The Logic of Provability, Cambridge University Press, New York.

Frege, Gottlob, 1979, Posthumous Writings, Blackwell, Oxford.

Hahn, L. and P. Schilpp (eds.), 1986, The Philosophy of W.V. Quine, Open Court, Chicago.

Quine, W.V.O., 1944, O Sentido da Nova Lógica, Martins Fontes, São Paulo.

Received: June 5, 2011; accepted: September 28, 2012. 